Auto Mania 



\section{Auto Mania}

Cars, Consumers, and the Environment

Tom McCarthy

Yale University Press

New Haven \& London 
Published with assistance from the foundation established in memory of William McKean Brown and from the income of the Frederick John Kingsbury Memorial Fund.

Copyright (๑) 2007 by Tom McCarthy. All rights reserved.

This book may not be reproduced, in whole or in part, including illustrations, in any form (beyond that copying permitted by Sections 107 and 108 of the U.S. Copyright Law and except by reviewers for the public press), without written permission from the publishers.

Set in Electra and Trajan types by Tseng Information Systems, Inc. Printed in the United States of America.

Library of Congress Cataloging-in-Publication Data

McCarthy, Tom, 1959-

Auto mania : cars, consumers, and the environment / Tom McCarthy.

p. $\quad \mathrm{cm}$.

Includes bibliographical references and index. ISBN 978-0-300-11038-8 (clothbound : alk. paper)

1. Automobile industry and trade-United States - History-2oth century. 2. Automobiles-Environmental aspects - United States-History - 2oth century.

3. Consumer behavior-United States-History-2oth century. I. Title.

$$
\begin{gathered}
\text { HD9710.U52M427 } 2007 \\
338.4^{\prime} 762922209730904-\mathrm{dc} 22 \quad 2007014691
\end{gathered}
$$

A catalogue record for this book is available from the British Library.

The paper in this book meets the guidelines for permanence and durability of the Committee on Production Guidelines for Book Longevity of the Council on Library Resources. 
For Mom and Dad

For Rory and Mac

And for Lisa 
